\title{
Synthesis and Study of Naphthacenedione (TQ) as a Photosensitizer for One- Electron Oxidation of DNA
}

\author{
Lezah W. Roberts and Gary B. Schuster* \\ Department of Chemistry and Biochemistry, Georgia Institute of \\ Technology, Atlanta, Georgia, 30332.
}

Gary.schuster@cos.gatech.edu

\section{Supporting Information}


5,12-Dihydro-5,12-dioxo-2-naphthacenecarboxylic Acid (3). A 900 mg (3.0 mmol)

portion of aldehyde 2 was dissolved in $50 \mathrm{~mL}$ of a 1:1 mixture of acetic acid and acetone and cooled to $0^{\circ} \mathrm{C}$ in an ice bath. A chromic acid solution containing $2.2 \mathrm{~g}(22 \mathrm{mmol})$ of chromium trioxide, $3.5 \mathrm{~g}$ sulfuric acid, $11 \mathrm{~mL}$ acetic acid, and $7 \mathrm{~mL}$ of water was prepared and this solution was slowly added to the aldehyde solution and warmed slowly to room temperature while being stirred. After ca. $7 \mathrm{hr}$, the TQ acid (3) precipitated and the solution turned green. The mixture was poured into $100 \mathrm{~mL}$ of water and the product was removed by vacuum filtration, washed with water and dried to yield $443 \mathrm{mg}$ (49\%)

of 3 as a yellow solid. ${ }^{1} \mathrm{HNMR}\left(300 \mathrm{MHz}, \mathrm{DMSO}-d_{6}\right) \delta 7.80$ (d of d, 2H, aromatic), 8.30 (d of d, 2H, aromatic), $8.40(\mathrm{~d}, 2 \mathrm{H}$, aromatic) $8.78(\mathrm{~s}, 1 \mathrm{H}$, aromatic), $8.89(\mathrm{~d}, 2 \mathrm{H}$, aromatic) MS (EI, 70eV) $m / z 302$.

2-(2'-Hydroxyethyl)-naphthacenecarboxamide, 5,12-dihydrox-5,12-dioxo (4). A 500 $\mathrm{mg}(1.7 \mathrm{mmol})$ portion of acid $\mathbf{3}$ was suspended in $15 \mathrm{~mL}$ of thionyl chloride and heated at reflux for $3 \mathrm{~h}$ until all of the acid dissolved. The solution took on a satin appearance. The thionyl chloride was removed by distillation at aspirator pressure; the product remained as a brownish yellow residue. The acid chloride was dried under vacuum and used immediately. The acid chloride dissolved in $20 \mathrm{~mL}$ of $\mathrm{CH}_{2} \mathrm{Cl}_{2}$ was added slowly to a nitrogen-saturated $\mathrm{CH}_{2} \mathrm{Cl}_{2}$ solution $(80 \mathrm{~mL})$ containing $0.4 \mathrm{~mL}(6.6 \mathrm{mmol})$ of ethanolamine and $0.24 \mathrm{~mL}(1.8 \mathrm{mmol})$ triethylamine and stirred overnight at room temperature. The precipitated product was removed by vacuum filtration. The collected solid was recrystallized from isopropyl alcohol to yield $322 \mathrm{mg}(55 \%)$ of amide 4 as a 
pale yellow solid. ${ }^{1} \mathrm{HNMR}\left(300 \mathrm{MHz}, \mathrm{DMSO}-d_{6}\right) \delta 3.38(\mathrm{t}, 2 \mathrm{H}$, aromatic), $8.25-8.38$ (m, 4H, aromatic), $8.70(\mathrm{~s}, 1 \mathrm{H}$, aromatic). MS (EI, $70 \mathrm{eV}) \mathrm{m} / z 345$.

\section{2-((2-Cyanoethyldiisopropy phosphoramidite) 2'-hydroxyethyl)-} naphthacenecarboxamide, 5,12-dihydrox-5,12-dioxo (1). A $350 \mathrm{mg}(1.0 \mathrm{mmol})$ portion of amide 4 was suspended in $50 \mathrm{~mL}$ dry, nitrogen-saturated $\mathrm{CH}_{2} \mathrm{Cl}_{2}$ contained in a $100 \mathrm{~mL}$ three-neck round bottom flask under nitrogen, A $0.7 \mathrm{~mL}$ diisopropylethylamine was added to the $\mathrm{CH}_{2} \mathrm{Cl}_{2}$ solution followed by dropwise addition of $0.44 \mathrm{~mL}$ of 2cyanoethyldiisopropychlorophosphoramidite. The solution was stirred at room temperature for $1 \mathrm{~h}$ and became clear and brown-reddish. The product was purified by silica gel column chromatography using a solution of 45:45:10, hexane, ethyl acetate and triethyl amine as eluant. This process gave $520 \mathrm{mg}(95 \%)$ of 1 as yellow solid suitable for automated DNA synthesis. ${ }^{1} \mathrm{HNMR}\left(300 \mathrm{MHz}, \mathrm{CDCl}_{3}-d_{1}\right) \delta 1.2(\mathrm{~d}$ of d, $12 \mathrm{H}$, methyl), 2.55 ( $\mathrm{d}$ of $\mathrm{d}, 2 \mathrm{H}$, methylene), $3.60-3.70(\mathrm{~m}, 2 \mathrm{H}$, methane), $3.75-3.80(\mathrm{~m}, 2 \mathrm{H}$, methylene), 3.86 - 3.97 (m, 4H, methylene), 7.1 (br.t, 1H, amide), 7.7 ( $\mathrm{d}$ of d, $2 \mathrm{H}$, aromatic), $8.05-8.13(\mathrm{~m}, 2 \mathrm{H}$, aromatic), 8.40 (d of d 2H, aromatic) $8.65(\mathrm{~s}, 1 \mathrm{H}$, aromatic) 8.85 (d, 2H, aromatic). MS (EI, $70 \mathrm{eV}) \mathrm{m} / \mathrm{z}$ 444. ${ }^{31} \mathrm{PNMR}(400 \mathrm{MHz}, \mathrm{CDCl} 3-$ d1) d 149.17 .

2-Naphthacenecarboxalate, 5, 12-dihydro-5, 12-dioxo (5). An 84 mg (0.29 mmol) portion of aldehyde $2,549 \mathrm{mg}(1.56 \mathrm{mmol})$ of $\mathrm{MnO}_{2}$ and $28 \mathrm{mg}$ of acetic acid were dissolved in $80 \mathrm{~mL}$ of methanol in a $200 \mathrm{~mL}$ round bottom flask. A $76.6 \mathrm{mg}$ portion of $\mathrm{NaCN}$ was added and the reaction mixture was stirred overnight. Upon completion the mixture was filtered through celite to remove the $\mathrm{MnO}_{2}$ and purified by column 
chromatography on silica gel with methylene chloride as eluant to yield $76 \mathrm{mg}(83 \%)$ of 5 as a yellow solid. ${ }^{1} \mathrm{HNMR}\left(300 \mathrm{MHz}, \mathrm{CDCl}_{3}-d_{1}\right) \delta 4.0(\mathrm{~s}, 3 \mathrm{H}$, methyl), $7.70(\mathrm{~d}, 2 \mathrm{H}$, aromatic), $8.19(\mathrm{~d}, 2 \mathrm{H}$, aromatic), $8.40(\mathrm{~d}, 2 \mathrm{H}$, aromatic), $8.85(\mathrm{~d}, 2 \mathrm{H}$, aromatic) $9.00(\mathrm{~s}$, 1H, aromatic), MS (EI, $70 \mathrm{eV}) \mathrm{m} / z 316$.

Labeling of DNA. The DNA strand S2 was $\gamma_{-}^{32} \mathrm{P}$ labeled. by adding $5 \mu \mathrm{L}$ of the DNA to a microcentrifuge tube followed by $10 \mu \mathrm{L}$ of water, $2 \mu \mathrm{L}$ of buffer for T4 Polynucleotide Kinase, $2 \mu \mathrm{L}$ of T4 Polynucleotide Kinase enzyme and $1 \mu \mathrm{L}$ amount of $\gamma_{-}{ }^{32} \mathrm{P}$. The sample was incubated at $37{ }^{\circ} \mathrm{C}$ for $45 \mathrm{~min}$. The radiolabeled sample was purified on a $20 \%$ denaturing polyacrylamide gel electrophoresis (PAGE). The DNA band was visualized using autoradiography on Kodak film. The DNA band was excised from the gel and eluted using elution buffer $\left(0.5 \mathrm{M}\right.$ ammonium acetate $\left(\mathrm{NH}_{4} \mathrm{OAc}\right), 10 \mathrm{mM}$ of magnesium acetate $\left(\mathrm{Mg}(\mathrm{OAc})_{2}\right), 1 \mathrm{mM}$ EDTA, $\left.0.1 \% \mathrm{SDS}\right)$ at $37{ }^{\circ} \mathrm{C}$ for no less than $4 \mathrm{~h}$ followed by precipitation of the DNA using cold ethanol and glycogen as reported previously. After precipitation and drying, nanopure water was added to the samples until they contained 10,000 counts per $\mu \mathrm{L}$.

Hybridization. Hybridization was achieved by mixing the labeled strand $(\sim 10,000 \mathrm{cpm})$, TQ-DNA S1 $(5 \mu \mathrm{M})$ (or AQ-DNA in the AQ experiments) and the unlabeled S1 DNA (5 $\mu \mathrm{M})$ in $10 \mathrm{mM}$ sodium phosphate buffer solution. The samples were heated to $90{ }^{\circ} \mathrm{C}$ for $5 \mathrm{~min}$ and allowed to cool to room temperature.

TQ-DNA samples in microcentrifuge tubes were irradiated ca. $10 \mathrm{~cm}$ from a 150 watt $\mathrm{Xe} / \mathrm{Hg}$ Oriel lamp filtered with a glass plate that absorbed all light below $400 \mathrm{~nm}$. 
The samples were irradiated for 0 (dark control) 10 and 20 min. In a similar experiment, the AQ-DNA samples were irradiated in a Rayonet Photoreactor equipped with eight 350 nm lamps for 0 (dark control) 2 and 4 min. The samples were precipitated using cold ethanol and glycogen, dried and treated for 30 min with $100 \mu \mathrm{L}$ of $1 \mathrm{M}$ piperidine at $~ 90$ ${ }^{\circ} \mathrm{C}$ and dried. The piperidine treated samples were analyzed by $20 \%$ denaturing PAGE. The gels were dried and the cleavage bands were visualized by autoradiography.

Cyclic Voltammetry. The TQ ester (5) was dissolved in a nitrogen-saturated acetonitrile solution containing $0.1 \mathrm{M}$ tetrabutylammonium tetrafluoroborate as the supporting electrolyte. The reduction potential of the nitrogen-saturated solution was measured using a $\mathrm{CH}$ Instruments model 660 Electrochemical Workstation with a three electrode system consisting of an $\mathrm{Ag} / \mathrm{AgCl}$ electrode (reference), a platinum electrode (working) and platinum as the (auxiliary electrode). The sweep window ranged from $-2000 \mathrm{mV}$ to $1500 \mathrm{mV}$. The experiment was repeated using different set sweep rates varying from 100 $\mathrm{mV} / \mathrm{s}$ to $500 \mathrm{mV} / \mathrm{s}$. Ferrocene was measured in the same solvent and used as a standard for potential correction. The results are shown in Figure S2.

UV-Vis Spectroscopy. All UV-Vis data were obtained using a Hewlett Packard UV-Vis spectrophotometer. DNA concentrations were estimated by measuring the absorbance of each strand and using the extinction coefficient for the DNA strand calculated by the Schepartz Lab Biopolymer Calculator. 
The TQ ester (5) absorption spectrum was obtained by dissolving it in acetonitrile to make a $5 \mu \mathrm{M}$ solution. Using the absorbance observed at $400 \mathrm{~nm}$, the extinction coefficient was calculated to be $4200 \mathrm{M}^{-1} \mathrm{~cm}^{-1}$.

Phosphorescence. The phosphorescence spectrum of the TQ ester (5) was recorded with a SPEX Fluorolog, SPEX $16810.22 \mathrm{~m}$ Spectrometer. A $50 \mathrm{mM}$ sample was prepared in ethanol. The solution was placed in a tube, submerged in liquid nitrogen and excited at $400 \mathrm{~nm}$.

Melting of DNA. The melting temperature of the TQ-DNA duplex was measured on a Cary 1E UV-Vis Spectrophotometer. A $2.5 \mu \mathrm{M}$ solution of the TQ-DNA duplex in 10 $\mathrm{mM}$ phosphate buffer was prepared. The melting curve was monitored at $260 \mathrm{~nm}$ as the temperature was ramped from 15 to $90^{\circ} \mathrm{C}$. 

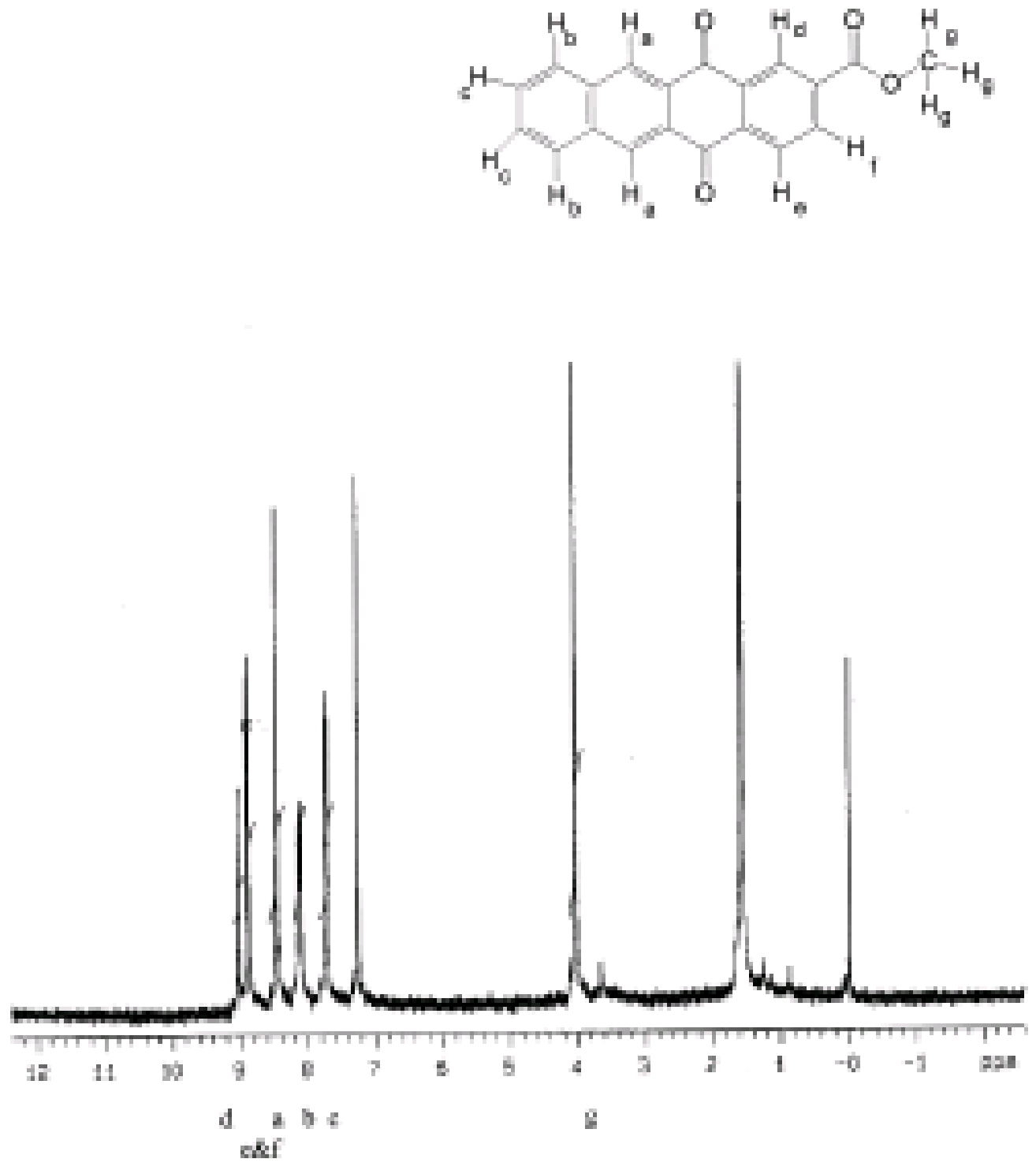

Figure S1. The NMR spectrum of the TQ ester (5) taken in chloroform- $d_{l}$. 


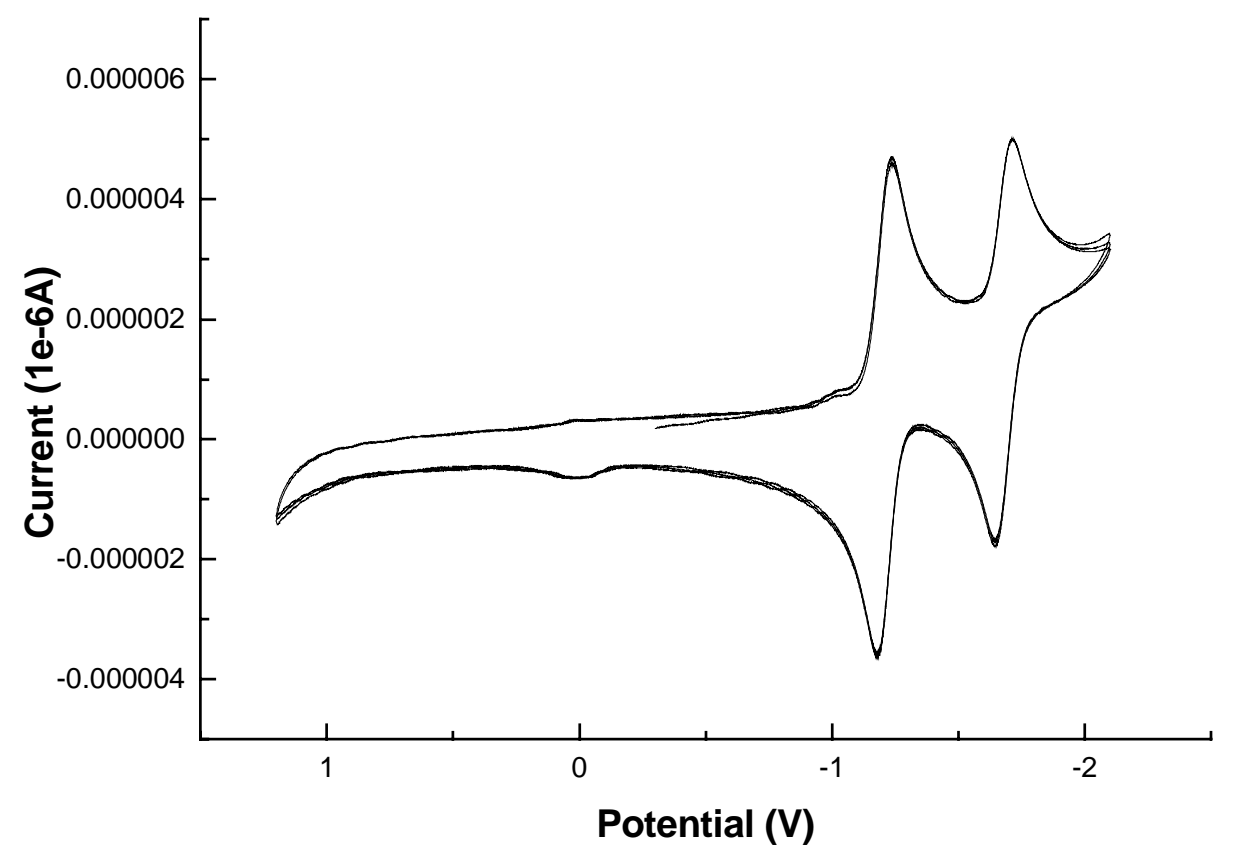

Figure S2. The cyclic voltammogram of the TQ ester (5) taken in a $0.1 \mathrm{M}$ solution of tetrabutylammonium tetrafluoroborate in acetonitrile. 


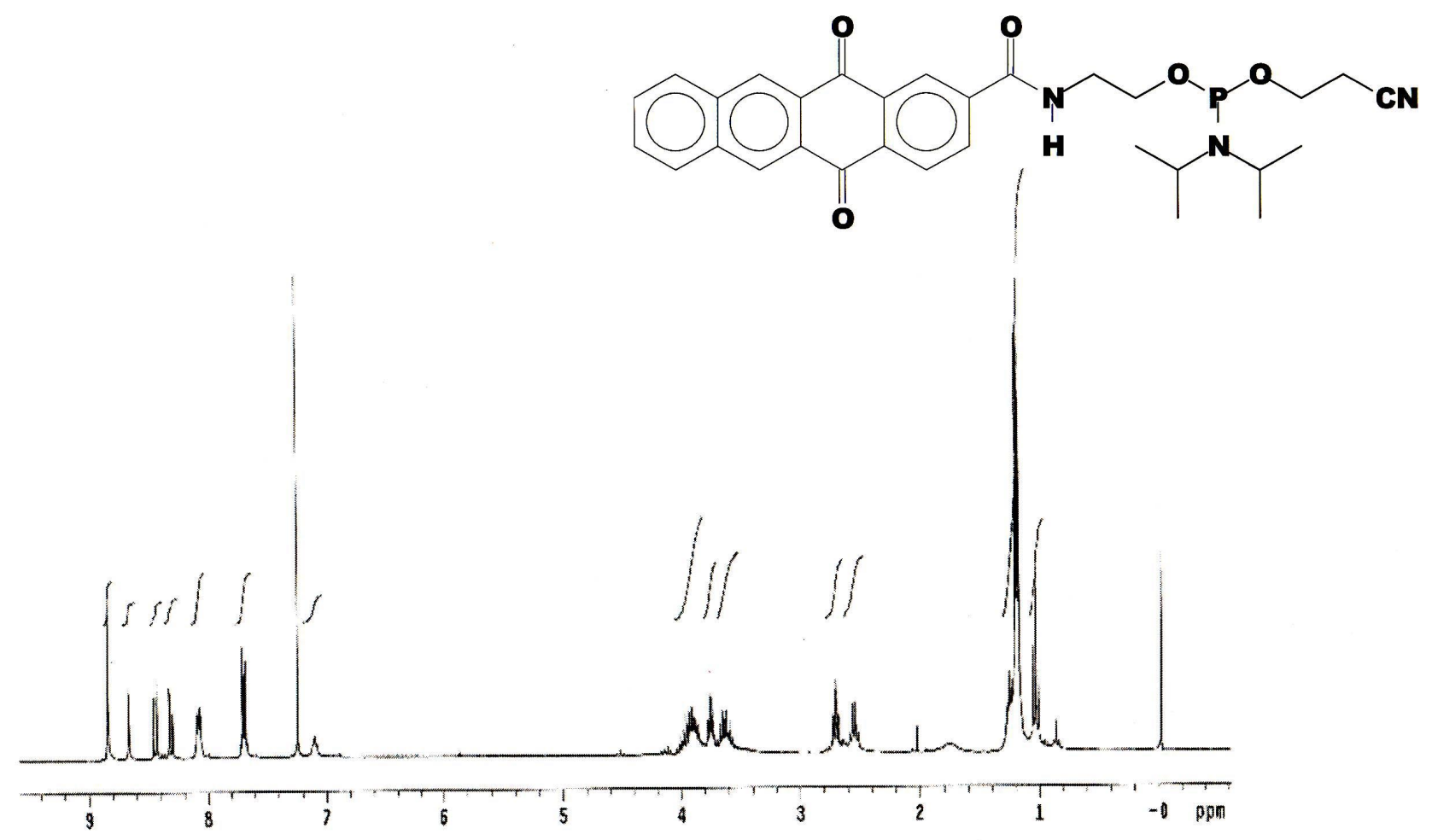

Figure S3. The NMR spectrum of the TQ phosphoramidite (1) taken in chloroform- $d_{l}$. 


\section{Melting Curve for TQ-DNA}

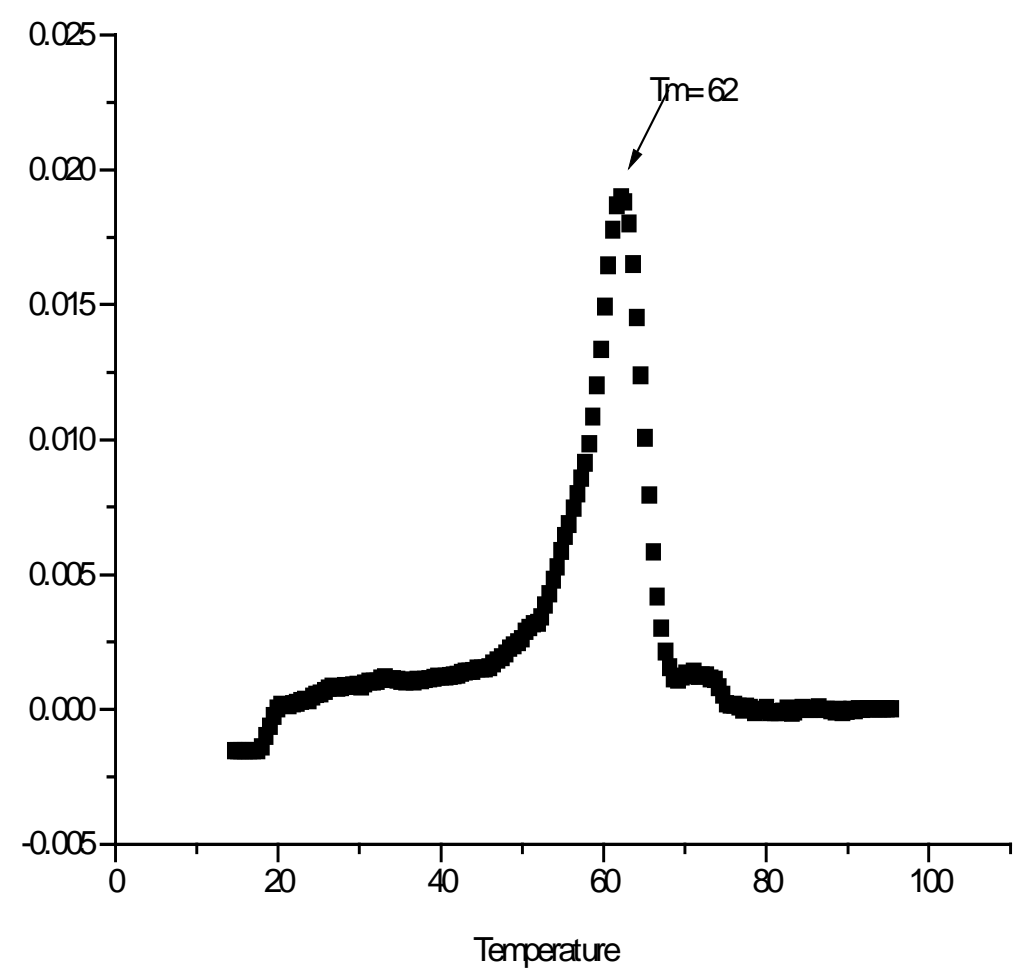

Figure S4. The first derivative melting curve of TQ-linked DNA(1) indicating a melting temperature of $62^{\circ} \mathrm{C}$. 